\title{
Peningkatan Mutu Produk UKM Melalui Sertifikasi Jaminan Produk Halal
}

\author{
${ }^{1 *}$ Lulu Nurul Istanti, ${ }^{2}$ Heri Pratikto, ${ }^{3}$ Yuli Agustina, ${ }^{4}$ Madziatul Churiyah, ${ }^{5}$ Andi Basuki \\ Universitas Negeri Malang; Jalan Semarang 5 Malang \\ *Corresponding author: lulu.nurul.fe@um.ac.id
}

\begin{abstract}
Abstrak
Kegiatan Pengabdian ini bertujuan untuk meningkatkan mutu produk melalui sertifikasi jaminan produk halal dengan memberikan pengetahuan, pemahaman dan pendampingan tentang pentingnya sertifikasi halal pada pelaku Usaha Kecil Menengah (UKM) di Kabupaten Trenggalek. Sesuai edaran LPPOM MUI bahwasannya di tahun 2019 seluruh produk yang berkaitan dengan makan dan minum harus memiliki sertifikasi halal. Hal ini menjadi salah satu tantangan bagi para pelaku UKM dalam memahami tentang arti pentingnya memiliki sertifikasi halal terhadap produk yang dimiliki. Diharapkan dengan adanya kegiatan ini akan menambah wawasan dan pengalaman yang dapat meningkatkan produktivitas dan daya saing bagi pelaku UKM. Kegiatan penyuluhan dilakukan melalui tahapan sosialisasi sampai pendampingan pendaftaran sertifikasi jaminan produk halal secara online pada 150 pelaku UKM yang bergerak di bidang kuliner, restoran, café maupun hotel. Penyuluhan Proses Sertifikasi Jaminan Produk Halal Usaha Kecil Menengah (UKM) yang telah dilakukan dapat dilihat dari antusiasme keikutsertaan UKM Kabupaten Trenggalek dan Peningkatan Pengetahuan dan kesadaran masyarakat serta pengembangan SDM bagi pelaku UKM di Kabupaten Trenggalek terkait jaminan produk halal.
\end{abstract}

Kata kunci-Penyuluhan, Sertifikasi Jaminan Produk Halal, UKM, Kabupaten Trenggalek.

\section{Abstract}

This Community Service activity aims to improve product quality through halal product assurance certification by providing knowledge, understanding and assistance on the importance of halal certification for Small and Medium Enterprises (SMEs) in Trenggalek Regency. According to the LPPOM MUI circular, in 2019 all products related to food and drink must have halal certification. This has become one of the challenges for SMEs in understanding the importance of having halal certification for their products. It is expected that this activity will add insight and experience that can increase productivity and competitiveness for SMEs. Counseling activities carried out through the stages of socialization to the assistance of online halal product assurance certification registration on 150 SMEs actors engaged in culinary, restaurants, cafes and hotels. Counseling of the Process of Certification of Halal Assurance for Small and Medium Enterprises (SMEs) that has been carried out can be seen from the enthusiasm of SME participation in Trenggalek Regency and the Increased Knowledge and public awareness and HR development for SMEs in Trenggalek Regency related to halal product guarantee.

Keywords-Counseling, Halal Product Guarantee Certification, UKM, Trenggalek Regency

\section{PENDAHULUAN}

$\mathrm{S}_{\mathrm{a}}^{\mathrm{a}}$ alah satu negara yang menjadi pasar potensial untuk produksi dan distribusi barang-barang halal adalah Indonesia. Hal ini dikarenakan penduduk indonesia merupakan mayoritas muslim terbesar di dunia, Indonesia diharapkan dapat menjadi contoh negeri muslim lain dalam penerapan hukum islam (syariat Islam) terutama dalam aspek yang bersentuhan langsung dengan kehidupan masyarakat muslim sehari-sehari. Penetapan tahun 2015 sebagai tahun pelaksanaan MEA (Masyarakat Ekonomi Asia) menjadi titik penting bagi pelaku UKM (Usaha Kecil Menengah) untuk lebih giat meningkatkan mutu produk dan layanan mereka. Hal tersebut merupakan konsekuensi semakin ketatnya persaingan antar pelaku usaha akibat interaksi global antar-produsen, antar-konsumen, serta antar-produsen dan konsumen, khususnya di wilayah Asia Tenggara. Sebagai konsekuensinya, pelaku UKM yang tidak kreatif dan 


\section{Istanti dkk. / Jurnal Karinov Vol. 2 No. 3 (2019) 198-203}

cermat dalam mengembangkan produknya dapat ditinggalkan oleh banyak konsumen yang lebih lanjut mengancam keberlanjutan UKM tersebut.

Untuk mengatasi hal tersebut, UKM, khususnya di Indonesia harus mendapatkan perhatian khusus dalam upaya meningkatkan mutu produk dan layanan mereka. Upaya tersebut merupakan salah satu tanggung jawab perguruan tinggi dalam mejalankan pelaksanaan Tri Darma Perguruan Tinggi. Upaya yang dapat dilakukan perguruan tinggi sebagai wujud tanggung jawabnya adalah kegiatan Pengabdian kepada Masyarakat yang berorientasi pada pembinaan kelompok UKM, khususnya UKM yang bidang usahanya terkait dengan kompetensi perguruan tinggi tersebut. Salah satu bentuk kegiatan yang telah dilaksanakan adalah penyuluhan proses sertifikasi halal yang disampaikan kepada para pelaku UKM yang ada di Kabupaten Trenggalek. Ini merupakan langkah awal yang harus diikuti untuk meningkaykan mutu produk melalui sertifikasi jaminan halal.

Jaminan halal merupakan faktor penting dalam memasarkan produk suatu UKM. Wilayah pemasaran yang semakin global menyebabkan konsumen suatu produk semakin heterogen. Konsumen yang heterogen menuntut kondisi produk yang sesuai dengan keinginan dan kriteria mereka. Salah satu kriteria yang sangat penting bagi konsumen adalah jaminan halal produk yang akan mereka beli. Kriteria ini merupakan tuntutan konsumen, tidak hanya yang beragama islam namun sudah menjadi tuntutan pasar secara global. Oleh karena itu, banyak perusahaan makanan dan produk pangan yang berupaya mencantumkan sertifikat halal pada produk mereka. Upaya ini tidak hanya dilakukan oleh perusahaan yang dijalankan oleh atau di komunitas muslim, tapi juga telah dilakukan oleh perusahaan yang dijalankan oleh atau di komunitas nonmuslim. Berbagai lembaga sertifikasi halal, baik milik pemerintah maupun swasta telah didirikan di beberapa negara nonmuslim seperti di Singapura, Jepang, Australia, Selandia Baru, Thailand, dan lain-lain. Hasilnya, produk mereka dapat diterima oleh banyak konsumen di berbagai negara yang mayoritas muslim seperti di Indonesia, Malaysia, Asia Selatan, dan Timur Tengah (Qureshi dkk., 2012).

Tidak hanya pada konsumen muslim, ketertarikan signifikan juga terjadi pada konsumen nonmuslim terhadap produk makanan yang bersertifikasi halal (Hanzaee \& Ramezani, 2011). Banyak hal yang menyebabkan ketertarikan konsumen nonmuslim tersebut, khususnya terhadap daging sembelihan. Salah satunya karena jaminan halal daging sembelihan tidak hanya berdasarkan ritual saat penyembelihan tapi juga memperhatikan faktor kesehatan dan kelayakan daging, kebersihan, dan umur hewan yang disembelih. Faktor-faktor tersebut meningkatkan nilai jual produk ternak bersertifikasi halal (Rezai dkk., 2010). Menanggapi kondisi pasar yang demikian, UKM di Indonesia khususnya yang bergerak di bidang pangan harus aktif pula melaksanakan jaminan halal bagi produk mereka. Kegiatan ini bertujuan untuk memberikan pengetahuan kepada pelaku UKM mengenai manfaat sertifikat halal produk sembelihan serta proses yang ditempuh untuk memperoleh sertifikat tersebut. Selain itu, kegiatan ini bertujuan untuk mendorong pemilik UKM agar segera menerbitkan sertifikat halal bagi produk mereka serta mendampingi beberapa UKM hingga dapat memiliki sertifikat tersebut dari LPPOM-MUI (Lembaga Pengkajian Pangan, Obat-obatan, dan Kosmetika-Majelis Ulama Indonesia).

Oleh karena itu, pelaksanaan kegiatan ini melibatkan auditor dari LPPOM-MUI, yakni auditor halal dari LPPOM-MUI. Selanjutnya, kegiatan pendampingan, pembinaan, dan pengawasan UKM yang telah memiliki sertifikat halal akan dilakukan Universitas Negeri Malang bersama LPPOM-MUI. Harapannya, kegiatan ini dapat dikembangkan pada sektor dan UKM yang lain. Pemerintah selaku pengatur urusan masyarakat memiliki kewajiban untuk memastikan bahwa makanan yang beredar dapat dikenali halal atau haramnya. Ketentuan halal atau haram ini terutama pada pemakaian zat dan bahan yang dalam memproduksi makanan dan minuman tersebut. Jaminan Produk Halal (JPH) dalam Undang-undang MUI Nomor 33 Pasal 4 Tahun 2014 tentang Jaminan Produk Halal (UUJPH), terdapat berbagai aspek tidak hanya obat, makanan dan kosmetik akan tetapi lebih luas lagi terdapat produk kimiawi, produk biologi, produk rekayasa genetik, serta barang gunaan yang dipakai, digunakan, atau dimanfaatkan oleh masyarakat (UUJPH, Pasal 1 ayat 1).

Mengenai model Sertifikasi Halal LPPOM MUI ini maka diperlukan sosialisasi atau penyuluhan dan penyadaran yang cukup gencar tentang arti pentingnya label halal baik ke UKM maupun konsumen. Karena jumlah penduduk muslim yang sangat banyak (baik jumlah maupun sebaran) serta banyaknya macam variasi dan jumlah produk makanan dan minuman yang beredar di tengah masyarakat maka dibutuhkan peran serta pemangku kepentingan, termasuk perguruan tinggi untuk memberikan penyuluhan agar menumbuhkan 
kesadaran dan pentingnnya sertifikasi halal sebagai jaminan kehalalan produk yang beredar di masyarakat. Kabupaten Trenggalek merupakan salah satu Kabupaten dengan jumlah penduduk muslim sebesar 853.056 jiwa. Berdasarkan data potensi industri di Kabupaten Trenggalek tahun 2017, tampak industri pengolahan pangan cukup banyak digeluti oleh masyarakat Kabupaten Trenggalek yaitu sebanyak 2.881 unit usaha.

Dari potret potensi industri Kabupaten Trenggalek tersebut tampak pengolahan pangan memiliki peran penting dan strategis dalam perekonomian masyarakat. Selama ini kesadaran atas konsumsi makanan dan minuman yang halal belum tertanam kuat di tengah-tengah masyarakat Kabupaten Trenggalek, baik dari kalangan produsen, penjual ataupun konsumen. Kondisi tersebut memperlihatkan tentang pemahaman dan kesadaran yang kuat atas ketentuan konsumsi halal dalam Islam. Kesadaran akan mengkonsumsi produk halal perlu ditingkatkan di tengah masyarakat Trenggalek, baik dari kalangan produsen, penjual maupun konsumen, agar terwujud tatanan masyarakat muslim yang sesuai syariat islam. Adapun tujuan kegiatan Pengabdian Peningkatan Mutu Produk UKM Melalui Sertifikasi Jaminan Produk Halal yaitu: (1) Peningkatan Pengetahuan dan kesadaran masyarakat serta pengembangan SDM bagi pelaku UKM di Kabupaten Trenggalek terkait jaminan produk halal; (2) Peningkatan Produktivitas dan daya saing UKM di Kabupaten Trenggalek pada Produk Halal; dan (3) Terciptanya peningkatan usaha produktif yang merupakan dampak kegiatan pemanfaatan energi serta potensi lokal dengan jaminan produk halal. Sedangkan manfaat yang diharapkan dari kegiatan Sosialisasi Sertifikasi Jaminan Produk Halal adalah (1) Meningkatkan pengetahuan dan pemahaman akan aspek manajerial serta pengembangan SDM bagi pelaku UKM di Kabupaten Trenggalek terkait jaminan produk halal; (2) Meningkatkan Produktivitas dan Daya Saing UKM di Kabupaten Trenggalek pada Produk Halal; dan (3) Terciptanya peningkatan usaha produktif yang merupakan dampak kegiatan pemanfaatan energi serta potensi lokal dengan jaminan produk halal.

\section{METODE}

Kegiatan Peningkatan Mutu Produk UKM Melalui Sertifikasi Jaminan Produk Halal di Kabupaten Trenggalek merupakan perwujudan pemahaman dan bentuk sosialisasi UU No 33 Tahun 2014 tentang sertifikat jaminan produk halal. Selain itu juga diharapkan dengan peraturan tersebut menyadarkan para pelaku usaha akan pentingnya sertifikasi halal pada produk usahanya dan berdampak pada peningkatan pendapatan masyarakat sekitar khususnya di Kabupaten Trenggalek. Pelatihan dilaksanakan di Kantor Sekretaris Daerah Kabupaten Trenggalek dan diikuti oleh pelaku UMKM sebanyak 150 peserta yang merupakan masyarakat perwakilan sekitar Kabupaten Trenggalek. Metode yang digunakan dalam program ini adalah pelatihan, pendampingan dan simulasi kegiatan pendaftaran sertifkasi halal secara manual dan online dengan mamanfaatkan aplikasi CEROL dan didampingi oleh mahasiswa, tim pengabdian dan masyarakat setempat.

Adapun metode yang diterapkan secara rinci yaitu: (1)Untuk mengetahui kebutuhan UMKM Kabupaten Trenggalek melalui observasi kondisi lingkungan dan kegiatan-kegiatan terkait, serta kelompok usaha yang tergabung pada kelompok UMKM Kabupaten Trenggalek dalam hal ini dilakukan melalui Pendekatan dengan Pemerintahan Dinas UKM setempat untuk mengetahui usaha produktif UKM dalam bidang makanan yang telah berkembang, untuk mengetahui kondisi pelaku UKM, pandangan dan pemahaman pelaku UKM terkait sertifikasi halal, serta mengidentifikasi permasalahan yang terkait; (2) Mendata macammacam kebutuhan teknis maupun non teknis pelatihan; (3) Pemberian sosialisasi tentang UU Jaminan Produk Halal bagi pelaku UKM (sektor pangan); (4) Sosialisasi Pengetahuan tentang Produk Halal sesuai arahan Badan Penyelenggaran Jaminan Produk Halal (BPJPH) RI; (5) Pelatihan peningkatan produksi produk halal; (6) Pelatihan dan pendampingan dalam proses penciptaan dan pengujian produk halal; dan (7) Pendampingan pengajuan sertifikasi produk halal. Analisis data dilakukan melalui pendekatan kualitatif. Pendekatan kualitatif dengan menganalisis data hasil diskusi dan observasi awal peserta dalam mengikuti kegiatan pelatihan.

\section{HASIL DAN PEMBAHASAN}

Analisis situasi yang telah dilakukan memperoleh hasil bahwa permasalahan yang dihadapi di UKM di Kabupaten Trenggalek adalah Kurangnya pengetahuan pada aspek manajerial usaha terkait dengan Label jaminan produk Halal pada Produk Makanan dan Minuman. Hal utama yang dihadapi oleh pemilik UKM di Kabupaten Trenggalek yaitu adanya keterbatasan pengetahuan 
yang dimiliki dalam manajerial usaha terkait dengan jaminan produk halal. Hal ini mengakibatkan usaha produktif sulit untuk berkembang dengan baik dan sesuai dengan peraturan Badan Penyelenggaran Jaminan Produk Halal (BPJPH) RI. Kegiatan pengabdian kepada masyarakat Penyuluhan Proses Sertifikasi Jaminan Produk Halal Usaha Kecil Menengah (UKM) Kabupaten Trenggalek. Melalui kegiatan Observasi dan FGD di Kabupaten Trenggalek bersama Dinas UKM setempat dan seluruh UKM pada tanggal 21-22 Maret 2019. Kegiatan awal ini dilakukan untuk mengidentifikasi permasalahan mengenai kendala sertifikasi halal UKM Kabupaten Trenggalek. Hasil yang dicapai dari kegiatan Focus Group Discussion (FGD) tersebut, karena masih kurangnya penyuluhan tentang produksi produk halal kepada pelaku usaha, termasuk mereka belum mendapatkan sosialisasi tentang Undang-Undang Jaminan Produk Halal. Selama ini, pelaku UKM mengolah produk makanan tanpa memperhatikan bahan-bahan yang terjamin kehalalan nya.

Hasil FGD menyatakan tim perlu melaksanakan kegiatan dalam bentuk Penyuluhan Proses Sertifikasi Jaminan Produk Halal Usaha Kecil Menengah (UKM) Kabupaten Trenggalek. Penyuluhan Proses Sertifikasi Jaminan Produk Halal ini diharapkan masyarakat dapat mengelola potensi local di daerah yang ada menjadi lebih bernilai jual secara ekonomi sehingga akan mampu meningkatkan kesejahteraan masyarakat secara keseluruhan.

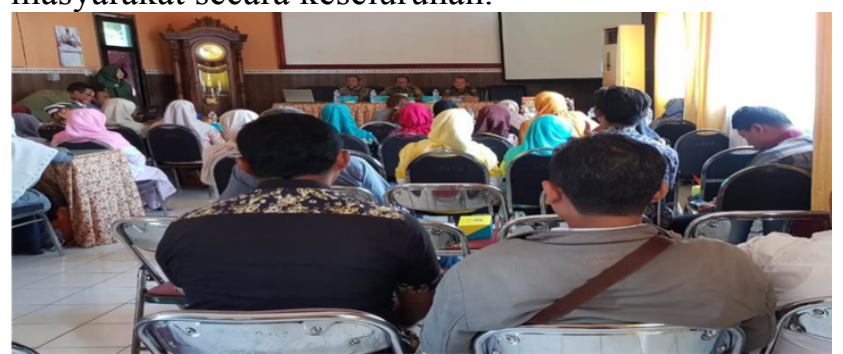

Gambar 1. FGD dengan Dinas UKM Kabupaten

Trenggalek dan Pelaku UKM setempat

Materi sosialisasi jaminan produk halal diawali tentang mengapa penting adanya sertifikasi Jaminan Produk Halal, apa saja yang harus dilakuakn untuk mendaftar sertifikasi produk halal. Saat kegiatan berlangsung peserta antusias dan terlihat serius. Selain karena materi tersebut merupakan pengetahuan baru bagi mereka, mereka juga memperoleh motivasi dalam mengembangkan bisnis mereka. Kegiatan Penyuluhan dan Sosialisasi dilaksanakan di kantor Dinas UMKM Kabupaten Trenggalek pada tanggal 24-25 April 2019. Penyuluhan dan Sosialisasi diawali dengan
Pembukaan Acara oleh Kepala Bidang Perdagangan Dinas Koperasi dan Usaha Mikro dan Perdagangan Kab. Trenggalek dan Ketua Tim, dan langsung dilanjutkan dengan kegiatan inti pemberian materi Penyuluhan dan Sosialisasi. sosialisasi ini materi yang disampaikan mengenai tentang UU No. 33 Tahun 2014 jaminan produk halal. Ringkasan materi yang disampaikan berdasarkan UU tersebut adalah tentang bahan apa saja yang digunakan dalam proses produk halal terdiri. Batrang tersebut terdiri dari bahan baku, bahan olahan, bahan tambahan, dan bahan penolong, yang berasal dari hewan, tumbuhan, mikroba, atau bahan yang dihasilkan melalui proses kimiawi, proses biologi, atau proses rekayasa genetik.

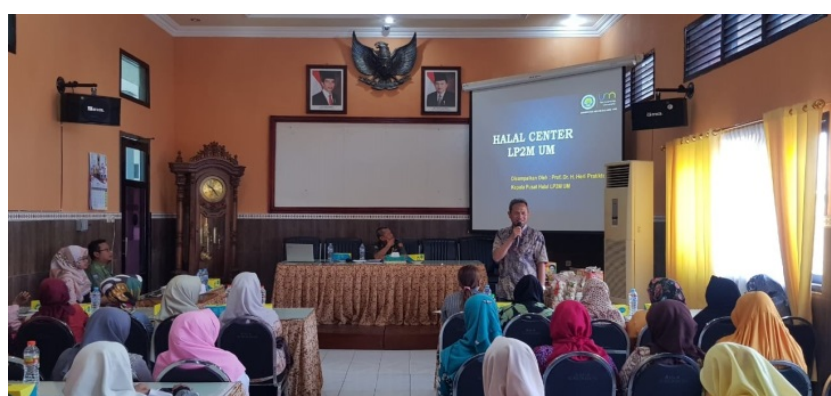

Gambar 2. Sosialisasi penyuluhan Jaminan Produk Halal

Dalam pelatihan tersebut para peserta yang hadir tampak sangat antusias mendengarkan penjelasan mengenai pentingnya sertifikasi Halal untuk produk usaha mereka kedepan. Hal ini tampak dari banyaknya Peserta yang bertanya dan ingin memperoleh penjelasan mendalam bagaimana cara mendapatkan sertifikat halal dengan mudah. Selain memberikan materi diatas, pemateri juga memberikan wawasan untuk memotivasi perserta untuk mendaftarkan produknya bersertikat halal.

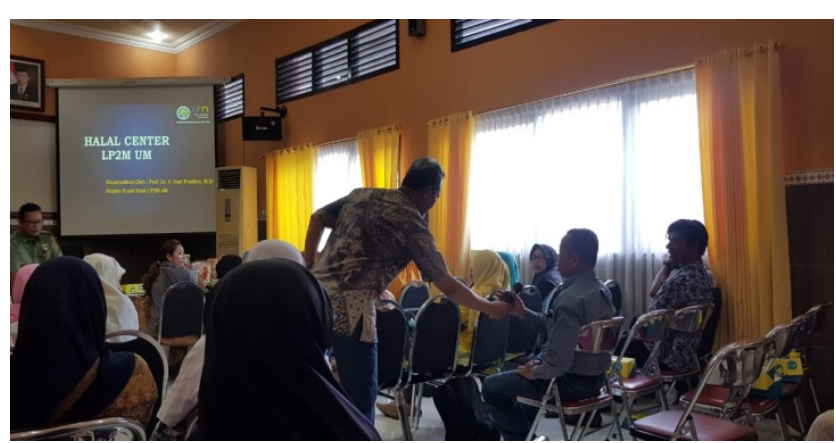

Gambar 3. Antusias Peserta yang mengikuti Sosialisasi 
Setelah selesai kegiatan sosialisasi dan pelatihan, Tim pengabdian melakukan pendampingan lanjutan pada UKM yang mengimplementasikan materi yang telah diajarkan. Pendampingan ini dilaksanakan selama 2 hari yakni pada tanggal 24-25 Juni 2019 dengan melakukan monitoring serta memberikan arahan agar mereka mampu mendaftarkan produk menggunakan CEROLSS23000 adalah sistem pelayanan sertifikasi halal LPPOM MUI secara online. Dengan sistem ini mereka dapat mengajukan permohonan sertifikasi halal produk secara online tanpa batas waktu dan tempat.

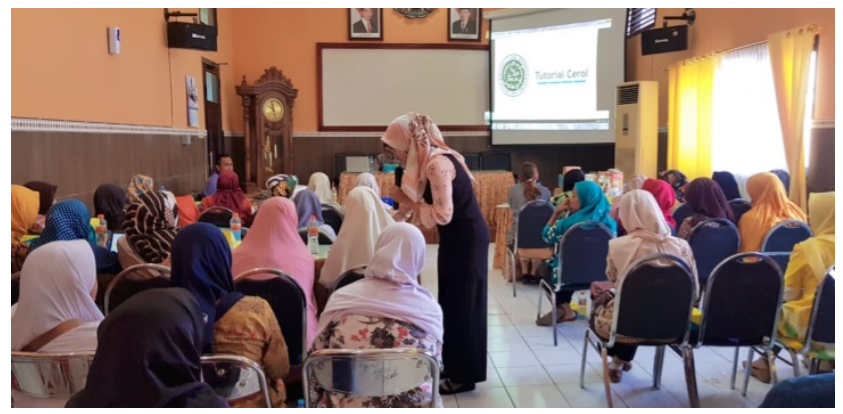

Gambar 4. Pendampingan pendaftaran sertifikat Halal seara Online Tahap 1 dengan aplikasi Cerol

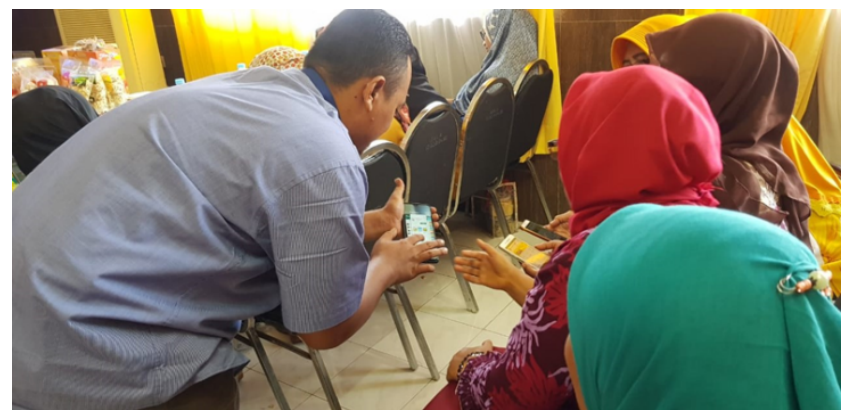

Gambar 5. Pendampingan pendaftaran sertifikat Halal seara Online Tahap 2 dengan aplikasi Cerol

Keberhasilan kegiatan pengabdian kepada masyarakat ini dapat diamati dari ketercapaian tujuan dan target yang telah direncanakan dan diharapkan saat pasca kegiatan ini diaksanakan para peserta mengalami peningkatan penambahan informasi dan wawasan jaminan produk halal, dengan adanya wawasan jaminan produk halal, UKM Kabupaten Trenggalek memiliki Unique Selling Point (USP) dan bisa bersaing serta mendapatkan kesempatan meraih pasar global dalam barang atau produk halal. Hal ini diharapkan mampu memperluas dampak positif bagi masyarakat sekitar. Dimana perkembangan usaha yang sudah bersertifikat halal mampu menciptakan penyerapan tenaga kerja baru.
Peserta penyuluhan dapat memahami materi penyuluhan dengan baik. Mereka dapat memahami bahwa sertifikat halal sangat penting dalam memasarkan produk mereka. Dengan adanya jaminan produk melalui sertifikasi halal, maka wilayah pemasarannya dapat diperluas hingga ke hotel dan rumah makan. Ini sangat memungkinkan karena Kabupaten Trenggalek merupakan kota yang memiliki banyak hotel dan rumah makan. Oleh karena itu, sebagian besar peserta ingin melengkapi produk mereka dengan sertifikat halal. Harapannya, wilayah pemasaran yang lebih luas akan meningkatkan pendapatan mereka. Selain itu, sertifikat halal pada produk mereka akan memberikan kenyamanan dan kepuasan pada konsumen. Konsumen dapat mengkonsumsi produk mereka tanpa khawatir mengenai status kehalalan dan kesehatan produk tersebut. pendampingan dalam pembuatan dokumendokumen yang dibutuhkan, khususnya dokumen Spesifikasi dan Sistem Jaminan Halal (SJH) yang diterapkan oleh masing-masing RPA.

Tahap sosialisasi dilaksanakan dalam bentuk penyuluhan. Sebagai tahap awal, tahap ini meliputi penyampaian hal-hal yang terkait dengan manfaat dan proses sertifikasi halal produk pangan, khususnya produk Rumah Potong Ayam (RPA). Selanjutnya, penyuluh juga menyampaikan bahwa sertifikat halal adalah fatwa tertulis Majelis Ulama Indonesia (MUI) yang menyatakan kehalalan suatu produk sesuai dengan syariat Islam (LPPOM-MUI, 2015). Sertifikat tersebut merupakan syarat untuk mendapatkan ijin pencantuman label halal pada kemasan suatu produk. Pencantuman label halal tersebut bertujuan untuk meyakinkan konsumen, khususnya konsumen muslim bahwa produk tertentu tersebut benar-benar produk halal.

Setiap produsen atau UKM yang ingin mengajukan sertifikasi halal untuk produknya harus mengisi formulir yang telah disediakan LPPOMMUI. Setelah diisi lengkap, formulir tersebut dikembalikan ke kantor LPPOM-MUI dilengkapi dengan dokumen Sistem Jaminan Halal (SJH) yang diuraikan dalam buku panduan halal beserta prosedur baku produksi. Dokumen-dokumen tersebut harus lengkap dan benar karena merupakan syarat pembuatan sertifikat. Jika dokumen tersebut lengkap dan benar, maka LPPOM-MUI akan mengirim tim auditor ke lokasi untuk mencocokkan dan memeriksa sistem jaminan halal di perusahaan tersebut. Sebaliknya, jika dokumen tersebut belum lengkap dan benar, maka seluruh berkas pengajuan akan dikembalikan agar dapat dilengkapi lagi. Laporan tim 
Istanti dkk. / Jurnal Karinov Vol. 2 No. 3 (2019) 198-203

auditor akan dibahas pada sidang internal LPPOMMUI. Jika memenuhi syarat halal, maka sertifikat halal akan diproses dalam sidang komisi fatwa MUI. Hasil dari sidang komisi fatwa MUI adalah penerbitan sertifikat halal bagi produk yang memenuhi syarat.

Rincian proses penerbitan sertifikat halal tersebut telah diterbitkan dan disebarkan oleh LPPOM-MUI dalam bentuk brosur memperlihatkan halaman brosur yang memuat prosedur penerbitan sertifikat halal, sementara gambar 6 memperlihatkan halaman brosur yang memuat format dokumen dokumen SJH. Brosur ini dibagikan saat acara penyuluhan sehingga peserta penyuluhan dapat memahami materi penyuluhan dengan baik.

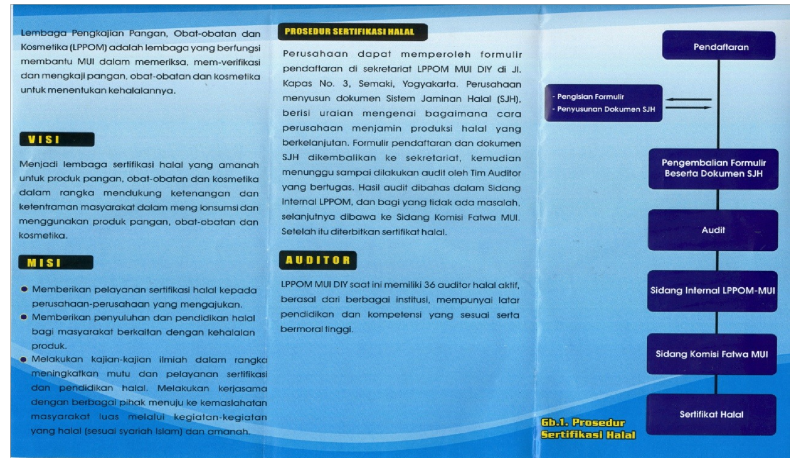

Gambar 6. Halaman brosur LPPOM-MUI yang memuat prosedur penerbitan sertifikat halal

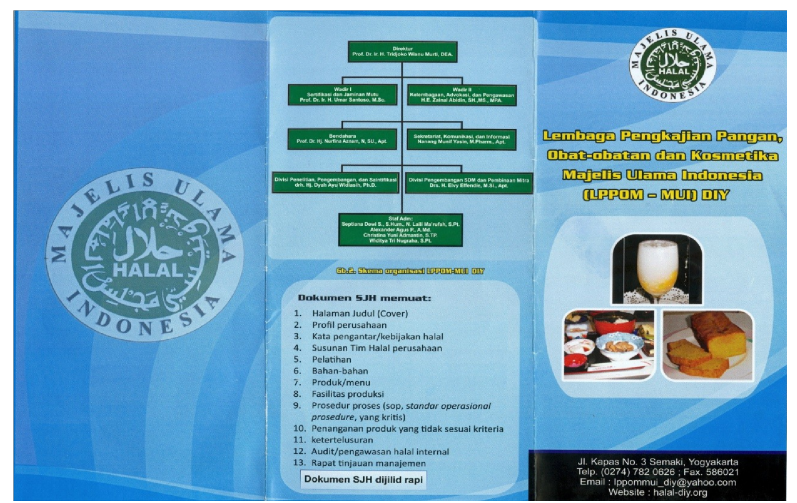

Gambar 7. Halaman brosur LPPOM-MUI yang memuat format dokumen dokumen $\mathrm{SJH}$

\section{SIMPULAN}

Tujuan dari Pengabdian ini adalah untuk meningkatkan mutu produk melalui sertifikasi jaminan produk halal dengan memberikan pengetahuan, pemahaman dan pendampingan tentang pentingnya sertifikasi halal pada pelaku Usaha Kecil Menengah (UKM) di Kabupaten Trenggalek. Sesuai edaran LPPOM MUI bahwasannya di tahun 2019 seluruh produk yang berkaitan dengan makan dan minum harus memiliki sertifikasi halal. Hal ini menjadi salah satu tantangan bagi para pelaku UKM dalam memahami tentang arti pentingnya memiliki sertifikasi halal terhadap produk yang dimiliki. Dengan adanya kegiatan ini akan menambah wawasan dan pengalaman yang dapat meningkatkan produktivitas dan daya saing bagi pelaku UKM. Kegiatan penyuluhan dilakukan melalui tahapan sosialisasi sampai pendampingan pendaftaran sertifikasi jaminan produk halal secara online pada 150 pelaku UKM yang bergerak di bidang kuliner, restoran, café maupun hotel. Penyuluhan Proses Sertifikasi Jaminan Produk Halal Usaha Kecil Menengah (UKM) yang telah dilakukan menghasilkan dampak yang baik dilihat dari antusiasme keikutsertaan UKM Kabupaten Trenggalek dan Peningkatan Pengetahuan dan kesadaran masyarakat serta pengembangan SDM bagi pelaku UKM di Kabupaten Trenggalek terkait jaminan produk halal. Selanjutnya, diharapkan dinas terkait dapat secara berkelanjuttan melakukan pendampingan dan motivasi pada para UKM untuk mendaftarkan produk usahanya pada sertifikat halal. Hal ini bertujuan pula untuk meningkatkan daya saing produk unggulan Kabupaten Trenggalek.

\section{DAFTAR RUJUKAN}

Apriyantono, A. (2013). LPPOM MUI Harus Diperkuat. Jurnal Halal, No.94.

Amin, M. (2013). Halal Berlaku untuk Seluruh Umat. Jurnal Halal. No. 101.Jakarta: LPPOM MUI.

Departemen Agama RI. (2003). Petunjuk Pedoman Sistem Produk Halal. Jakarta.

Hanzaee, K.H. dan Ramezani, M.R., (2011). Intention to halal Products in The World Markets. Interdisciplinary Journal of Research in Business, 1(5), 1-7.

Qureshi, S.S., Jamal, M., Qureshi, M.S., Rauf, M., Syed, B.H., Zulfiqar, M., dan Chand, N., (2012). A Review of Halal Food with Special Reference to Meat and Its Trade Potential. J Anim Plant Sci, 22 (2 Suppl), 79-83.

Rezai, G., Mohamed, Z., Shamsudin, M.N., \& Chiew, E.F.C. (2010). Non-Muslims' Awareness of Halal Principles and Related Food Products in Malaysia. International Food Research Journal, 17, 667-674.

Undang-undang No. 33 tahun 2014 tentang Jaminan Produk Halal.

http://www.halalmui-dki.org/wpcontent/uploads/2014/10/Logo-HalalMUIofficial.jpg 